\title{
Learning Model of Fundamental Movement Skills (FMS) for Children with Mild Intellectual Disability
}

\author{
Selvi Atesya Kesumawati ${ }^{1, *}$, Fakhruddin ${ }^{2}$, Husni Fahritsani ${ }^{3}$ \\ ${ }^{1}$ Faculty of Teacher, Education Science and Language, Universitas Bina Darma, Palembang, Indonesia \\ ${ }^{2}$ Faculty of Education, Universitas Negeri Semarang, Semarang, Indonesia \\ ${ }^{3}$ Faculty of Teacher, Education Science, Universitas PGRI, Palembang, Indonesia
}

Received September 22, 2020; Revised December 14, 2020; Accepted December 22, 2020

\section{Cite This Paper in the following Citation Styles}

(a): [1] Selvi Atesya Kesumawati, Fakhruddin, Husni Fahritsani , "Learning Model of Fundamental Movement Skills (FMS) for Children with Mild Intellectual Disability," International Journal of Human Movement and Sports Sciences, Vol. 9, No. 1, pp. 71-80, 2021. DOI: 10.13189/saj.2021.090110.

(b): Selvi Atesya Kesumawati, Fakhruddin, Husni Fahritsani (2021). Learning Model of Fundamental Movement Skills (FMS) for Children with Mild Intellectual Disability. International Journal of Human Movement and Sports Sciences, 9(1), 71-80. DOI: 10.13189/saj.2021.090110.

Copyright $\bigcirc 2021$ by authors, all rights reserved. Authors agree that this article remains permanently open access under the terms of the Creative Commons Attribution License 4.0 International License

\begin{abstract}
The backgrounds of this study are (1) the Fundamental Movement Skills (FMS) of children with mild Intellectual Disability (ID) experience barriers caused by mental disorders, (2) the limitations of teachers in developing play activities models to improve FMS of children with ID, (3) facilities and equipment in schools using for standard normal child. This study aims to produce a learning model to improve FMS for children with mild ID. The learning model is packaged in game activities, and takes one of the themes in the 2013 curriculum. This learning model is named activities in the morning. The research method used is research and development (R\&D) proposed by Borg and Gall. The R\&D procedure basically consists of two main objectives, namely: (1) developing products and; (2) testing the effectiveness of the product to achieve the goal. The subject of small group trial used 10 students ( 6 boys, 4 girls $8-10$ years old) and 4 teachers, and the large group trial used 23 students (13 boys and 10 girls 8-10 years old) and 4 teachers in the 3 SLB in Palembang city. The results of the effectiveness test of the different learning model activities in the morning in small and large group trials for aspects of movement skills, cognitive skill and fun are analyzed, and focus of attention in trials small and large group obtained an average value of trial 2 greater than trial 1 . Also, the calculated z-test is greater than the z-table value, so the difference is significant.
\end{abstract}

Keywords Movement, Play, ID

\section{Introduction}

Individuals with intellectual disability (ID) are individuals who have intelligence below the average of normal children (IQ $<70$ ). Mental Retardation is classified into 3, namely mild ID, moderate ID and severe ID. Children with ID in their daily lives need help from others to live their daily lives (not yet independent). Research on facilitating the learning of students with intellectual disabilities has increased considerably in the past few decades. Intellectual disability is defined as the disability which is characterized by limitation in learning as well as problem solving. The disability covers a wide range of behaviours and starts before the age of 18 . It includes wide range of disabilities like poor problem-solving abilities, behavioural issues, delay in development of motor skills (walking, running, sitting) and difficulty is following society rules and norms[1]. If we want mental disabled people to live a more active and healthy life, we should encourage them to do sports and provide support. The disabled people's active participation in the sport by getting out of their home life will make them more active individuals within the society[2]. Sharing of same environment together with the individuals with Down's syndrome and healthy individuals will provide them to live a more active and creative life in their daily lives. Zikl, 
et.al (2013) Improving motor skills is thus one of the areas that can help to better the inclusion of people with mild intellectual disabilities and is one of the prerequisites for having a normal life[3].

One of the formal institutions that serve children with ID in Indonesia is a special school (SLB). SLB type C in Indonesia serves formal education for children with ID ranging from elementary to high school levels. In SLB C, children with ID are given PE Adapted learning. Nowadays, inclusive schools or SLB should be characterized by a high level of commitment in teacher training. To achieve this goal, teachers should be trained in teaching competences in contexts of a great diversity. Their task will be to teach intellectually disabled students by adapting the educational contents through the use of educational resources[4], but based on the results of observations [2017] conducted by researchers in the three special schools education serving children with ID at the elementary school level, it obtained data that are the FMS, the data obtained are as follows;

(1) Children with ID experience disturbances and obstacles in carrying out movements, experience difficulties in adapting and social interaction, especially those related to moving movement.

(2) FMS and physical fitness level of children with mild and moderate ID at primary school special education Palembang City are still low.

(3) Physical education learning materials provided by teachers are still less varied because the teacher's ability to develop models is still inadequate.

(4) Implementation of physical education has not become an optimal means of addressing problems or movement barriers for children with ID in primary school special education Palembang City.

(5) There is no collaboration between physical education teachers, class teachers, and teachers of other subjects to collaborate in making learning material as outlined in the physical activities of children with ID.

The process of education for children is an important thing that needs to get attention from various parties. Education in schools has an important role and has covered two important aspects of social aspects and individual aspects. Education also serves to influence and create a condition that allows it to help the child's development optimally[5]. To reduce physical inactivity in children with ID that will have an impact on their health as revealed by WHO (2009) identified physical activity as a preventative health measure that is critically important for the health and well-being of people of all ages. Evidence from the past 10 years has suggested that physical activity levels in people with intellectual disabilities (IDs) are low and sedentary[6], learning PE Adapted must be adjusted to the characteristics and barriers of children with ID.

Based on the results of the preliminary study, the researcher and team developed a Physical Education learning model specifically designed for children with mild ID, especially those related to FMS, because FMS are an asset for everyone without exception children with ID as a provision for carrying out daily activities without significant obstacles[7].

Educators often face difficulties in securing the resources they need in order to teach effectively. This is especially true of physical educators, who rely on equipment to help young people develop and practice physical skills. And it's all the more so in adapted physical education, where modified and specialized equipment can be costly but is essential in order for educators to serve the developmental needs (and IEP goals) of students with disabilities. Unfortunately, the cost of physical education equipment continues to rise as funding continues to be reduced or even eliminated, and modified equipment costs are even more than general equipment[7].

The model development carried out in this study is the development of Fundamental Movement learning model through playing activities to increase FMS for children with mild ID by modifying equipment, game rules and movement activities that are tailored to the characteristics and needs of children with mild ID.

Teachers need to reduce verbalization of instructions and emphasize tactile, kinesthetic, visual, and other more concrete forms of instruction. Children who cannot readily transfer learning or apply past experiences to new situations need more gradual task progressions in smaller sequential steps and need to learn and practice skills in the environments in which they are used. It is also important to consider level of cognitive development in teaching rules and game strategies. As cognition develops, more complex rules and strategies can be introduced [5].

Children with ID have differences in cognitive behavior with normal children of his age, the higher the level of disability, the lower the cognitive level. Other characteristics affecting learning are a limited ability to generalize information, short attention span, and inability to understand abstract concepts.

Based on the background of the problem and the researchers' preliminary studies, the researchers developed a fundamental movement learning model for children with ID.

\section{Learning Model Activities in the Morning}

The fundamental movement learning model through play activities was developed according to the theme of the 2013 curriculum. The theme of the game in this study is "Activities in the Morning". This model consists of 3 game posts, and each post has a task of movement and different media and equipment. The objectives to be achieved in this game are: (1) to increase backward walking movement skills, (2) to increase hooping and 
jumping movement skills, (3) to increase throwing skills, (4) to increase cognitive skills, focus attention and pleasure[8].

\subsection{Learning Model Activities in the Morning Post 1}

Playing activities in post 1 , using the following equipment: (1) 8 pieces of evamat $30 \times 30 \mathrm{~cm}$, each modified with a different textures (fine synthetic grass, gravel, coarse grass, mat, bottles cap, dacron, grain, fondant), (2) flashcards with food and drink picture, (3) numeric flashcards, (4) tape, (5) flags (cones), (6) whistles.

The implementation of playing activities in post 1 by way of students doing back right then taking one of the food flashcards and counting the number, after instruction from the teacher made the movement to walk backward over the evamat various textures to the finish line to pick up a flashcard with a number matches the amount of food on the flashcard, after finishing the child leaves the playing field and prepares for the next post.

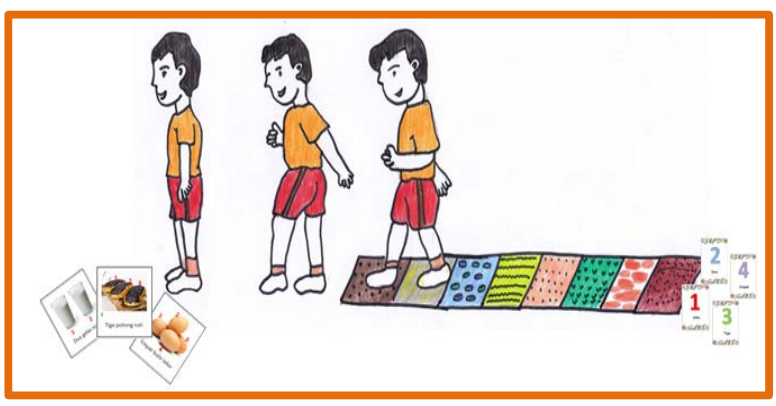

Figure 1. Game Model Activities in the Morning Post 1

\subsubsection{Assessment Rubric Learning Model Activities Post 1}

\section{(1) Movement Skill Aspect's Rubric Assessment}

score 4, if students can do without the help of others. score 3, if students can do it with a little help from others.

score 2, if students can do it with the full help of others.

score 1 , if students need special guidance to be able to make movements.

\section{(2) Cognitive Aspect's Rubric Assessment}

score 4, if students can take the flashcard the right number according to the picture.

score 3, if the participant tries to take a numeric flashcard even though it doesn't match the picture.

score 2, if students can take flashcards with a little number of teacher guidance.

score 1, if students can take flashcards with full assistance.

\section{(3) Fun Aspect's Rubric Assessment}

score 4, if the student shows a cheerful facial expression and is sometimes accompanied by cheerful laughter.

score 3, if the student shows a cheerful facial expression and sometimes smiles broadly while enjoying the game.

score 2, if students do not show feelings of pleasure (do movements at will and carelessly).

score 1, if the student does not feel happy (sullen facial expression and as if forced to make a movement).

\section{(4) Focus Attention Aspect's Rubric}

score 4, if students are very focused on doing the movement (from start to finish, and are not disturbed by the surroundings)

score 3, if the focus of the students' attention is slightly distracted, sometimes they still look left and right.

score 2, if students do not focus and often stop when doing movement tasks

score 1 , if the student is very unfocused and cannot complete the task.

Table 1. Assessment Rubric of Learning Model Activities Post 1

\begin{tabular}{|c|c|c|c|c|c|c|}
\hline No & Student Name & $\begin{array}{l}\text { Movement Skills } \\
\text { Aspect }\end{array}$ & Cognitive Aspect & $\begin{array}{c}\text { Fun Activity } \\
\text { Aspect }\end{array}$ & $\begin{array}{c}\text { Focus Attention } \\
\text { Aspect }\end{array}$ & Score Total \\
\hline 1. & & & & & & \\
\hline 2. & & & & & & \\
\hline 3. & & & & & & \\
\hline 4. & & & & & & \\
\hline eg & & & & & & \\
\hline
\end{tabular}




\subsection{Learning Model Activities in the Morning Post 2}

Playing activities in post 2, using the following equipment: (1) 5 pieces of hoops made with hoses of 30 $\mathrm{cm}$ diameter, (2) 3 pieces of fabric balls with a diameter of $15 \mathrm{~cm}$, (3) footprint, (4) tape, (5) cones, and (6) whistle. The procedure for implementing the game in post 2 is by the child standing ready to wait for the whistle from the teacher and immediately taking the ball, hugging it to the chest then making hoping or jumping movements according to the footprint instructions and inserting the fabric ball into the basket provided, and return to the starting line by walking and repeating 3 times (according to the number of balls provided), after finishing, the child leaves the playing field and prepares for the next post.

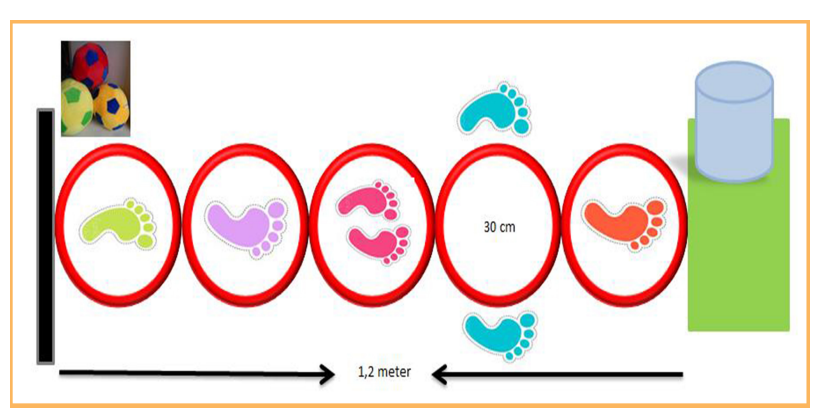

Figure 2. Game Model Activities in the Morning Post 2

2.2.1. Assessment Rubric Learning Model Activities Post 2

\section{(1) Movement Skill Aspect's Rubric Assessment}

score 4, if students can do without the help of others. score 3, if students can do it with a little help from others.

score 2, if students can do it with the full help of others. score 1 , if students need special guidance to be able to make movements.

\section{(2) Cognitive Aspect's Rubric Assessment}

score 4, if students can count the number of circles correctly.

score 3 , if students try to count the number of circles even though it is not correct.

score 2, if students can count the number of circles with a little direction from the teacher.

score 1 , if students can count the number of circles with full help from the teacher.

\section{(3) Fun Aspect's Rubric Assessment}

score 4, if the student shows a cheerful facial expression and is sometimes accompanied by cheerful laughter.

score 3, if the student shows a cheerful facial expression and sometimes smiles broadly while enjoying the game.

score 2, if students do not show feelings of pleasure (do movements at will and carelessly).

score 1, if the student does not feel happy (sullen facial expression and as if forced to make a movement).

\section{(4) Focus Attention Aspect's Rubric}

score 4, if students are very focused on doing the movement (from start to finish, and are not disturbed by the surroundings)

score 3, if the focus of the students' attention is slightly distracted, sometimes they still look left and right.

score 2, if students do not focus and often stop when doing movement tasks.

score 1 , if the student is very unfocused and cannot complete the task.

Table 2. Assessment Rubric of Learning Model Activities Post 2

\begin{tabular}{|c|c|c|c|c|c|c|}
\hline No & Student Name & $\begin{array}{c}\text { Movement Skills } \\
\text { Aspect }\end{array}$ & Cognitive Aspect & $\begin{array}{c}\text { Fun Activity } \\
\text { Aspect }\end{array}$ & $\begin{array}{c}\text { Focus Attention } \\
\text { Aspect }\end{array}$ & Score Total \\
\hline 1. & & & & & & \\
\hline 2. & & & & & & \\
\hline 3. & & & & & & \\
\hline 4. & & & & & & \\
\hline eg & & & & & & \\
\hline
\end{tabular}




\subsection{Learning Model Activities in the Morning Post 3}

Playing activities in post 3 , using the following equipment: (1) 3 pieces bean bag colors (1 pieces red color, 1 pieces blue color, and 1 pieces yellow color), (2) 15 plastic glasses color, (3) tape and (4) whistle. The procedure for implementing post 3 playing activities is by way of students throwing (underhand throw) bean bags towards the target. After finishing, game is completed.

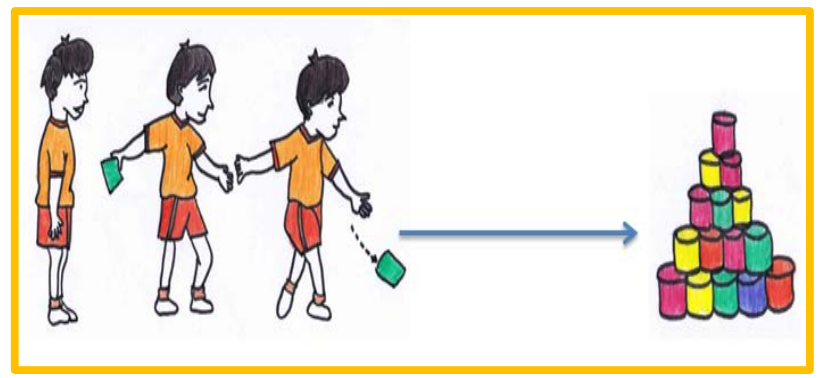

Figure 3. Game Model Activities in the Morning Post 3

\subsubsection{Assessment Rubric Learning Model Activities Post 3}

\section{(1) Movement Skill Aspect's Rubric Assessment}

score 4, if students can do without the help of others. score 3 , if students can do it with a little help from others.

score 2, if students can do it with the full help of others. score 1 , if students need special guidance to be able to make movements.

\section{(2) Cognitive Aspect's Rubric Assessment}

score 4 , if students can count the number of glasses that have fallen correctly.

score 3, if students try to count the number of glasses that have fallen even though it is not correct.

score 2, if students can count the number of glasses that have fallen under the direction of the teacher.

score 1, if students can count the number of glasses that have fallen with the full help of the teacher.

\section{(3) Fun Aspect's Rubric Assessment}

score 4, if the student shows a cheerful facial expression and sometimes accompanied by cheerful laughter.

score 3, if the student shows a cheerful facial expression and sometimes smiles broadly while enjoying the game.

score 2, if students do not show feelings of pleasure (do movements at will and carelessly).

score 1, if the student does not feel happy (sullen facial expression and as if forced to make a movement).

\section{(4) Focus Attention Aspect's Rubric}

score 4, if students are very focused on doing the movement (from start to finish, and are not disturbed by the surroundings)

score 3, if the focus of the students' attention is slightly distracted, sometimes they still look left and right.

score 2, if students do not focus and often stop when doing movement tasks.

score 1 , if the student is very unfocused and cannot complete the task.

Table 3. Assessment Rubric of Learning Model Activities Post 3

\begin{tabular}{|c|c|c|c|c|c|c|}
\hline No & Student Name & $\begin{array}{c}\text { Movement Skills } \\
\text { Aspect }\end{array}$ & Cognitive Aspect & Fun Activity Aspect & $\begin{array}{c}\text { Focus Attention } \\
\text { Aspect }\end{array}$ & Score Total \\
\hline 1. & & & & & & \\
\hline 2. & & & & & & \\
\hline 3. & & & & & & \\
\hline 4. & & & & & & \\
\hline Eg & & & & & & \\
\hline
\end{tabular}




\subsection{Method}

Borg and Gall, development research researcher oriented to develop and validate[9] products used in education based on the procedural model proposed by Borg and Gall, and the research and development procedure basically consists of two main objectives, namely: (1) developing products and; (2) testing the effectiveness of the product to achieve the goal. The first objective is referred to as the validation function while the second objective is called the effectiveness test function. The main procedure in research and development consists of five steps, namely: (1) Analyzing the product to be developed, (2) Developing the initial product, (3) Expert validation, (4) Empirical validation (field trials), (5) Product revision.

The product trial design in research and development uses a pre-experimental method with a single one shot case study design. The subjects of the trial were PE Teachers and student with mild ID 1st class in SLB Palembang. The types of data in this study are qualitative and quantitative. Instrument for teacher opinion used is a questionnaire. The instrument for collecting data on learning outcomes using non-test techniques is observation (rubric assessment). The data analysis technique used the $t$ test and the Wilcoxon test.

\subsubsection{The Data Collection Technique}

The learning model activities in the morning that had been designed by the researcher were evaluated by 4 experts, consisting of;1 Expert material PE adaptive, 1 psychologist education, 1 Expert planning learning children with special needs, and 1 Teacher PE special ID, The activities at this stage evaluate and revise the product if necessary. Data collection techniques assessment by experts uses a rating scale. The value scale used is guided by a predetermined grid by adjusting to the research objectives.

Table 4. Instructional Rating Scale

\begin{tabular}{|c|l|}
\hline Scale & \multicolumn{1}{|c|}{ Assessment Description } \\
\hline 1 & $\begin{array}{l}\text { very inappropriate / very imprecise / very } \\
\text { unsafe / very not easy / very impractical / very } \\
\text { unsafe }\end{array}$ \\
\hline 2 & $\begin{array}{l}\text { inappropriate / inappropriate / unsafe / not easy } \\
\text { / impractical / unable to optimize }\end{array}$ \\
\hline 3 & $\begin{array}{l}\text { appropriate / precise / safe / easy / practical / } \\
\text { can optimize }\end{array}$ \\
\hline 4 & $\begin{array}{l}\text { very suitable / very precise / very safe / very } \\
\text { easy / very practical / highly optimizing }\end{array}$ \\
\hline
\end{tabular}

After getting an assessment from the four experts, the next step is to analyzed the data that have been obtained to determine the level of validity of the model "activities in the morning" using the Content Validation Index (CVI) and Content Validity Ratio (CVR), table 5.

The next stage is empirical validation or field trials; field trials consist of 2 stages, namely (1) small group trials and (2) large group trials. The small group trial involved 10 students aged 8-10 years consisting of 6 boys and 4 girls, and 4 teachers of SDLB C Karya Ibu Palembang. The large group trial involved 23 students aged 8-10 years consisting of 13 boys and 10 girls, and 4 teachers of SDLB C Karya Ibu, SDLB C YPAC, SDLB B Pembina Palembang.

Table 5. Instrument of Assessment Expert Validation

\begin{tabular}{|c|c|c|c|c|c|}
\hline \multirow[t]{2}{*}{ No } & \multirow{2}{*}{ Aspect of Assess } & \multicolumn{4}{|c|}{$\begin{array}{l}\text { Rating } \\
\text { Scale }\end{array}$} \\
\hline & & 1 & 2 & 3 & 4 \\
\hline 1. & $\begin{array}{l}\text { The suitability of the game model developed } \\
\text { with competency standards and basic } \\
\text { competencies and indicators. }\end{array}$ & & & & \\
\hline 2. & $\begin{array}{l}\text { The suitability between indicators and subject } \\
\text { matter and assessment. }\end{array}$ & & & & \\
\hline 3. & $\begin{array}{l}\text { The accuracy of the contents of the FMS } \\
\text { learning model developed for SLB students } \\
\text { with intellectual disabilities. }\end{array}$ & & & & \\
\hline 4. & $\begin{array}{l}\text { The accuracy of the contents of the FMS } \\
\text { learning model developed with the } \\
\text { characteristics of the SLB students with } \\
\text { intellectual disabilities. }\end{array}$ & & & & \\
\hline 5. & $\begin{array}{l}\text { The safety of the FMS learning model } \\
\text { developed. }\end{array}$ & & & & \\
\hline 6. & Ease of the developed FMS learning model. & & & & \\
\hline 7. & $\begin{array}{l}\text { Practicality of the developed FMS learning } \\
\text { model. }\end{array}$ & & & & \\
\hline 8. & $\begin{array}{l}\text { The FMS learning model developed can } \\
\text { increase the activeness of children with ID in } \\
\text { SLB. }\end{array}$ & & & & \\
\hline 9. & $\begin{array}{l}\text { The FMS learning model developed can } \\
\text { optimize the (cognitive) knowledge of } \\
\text { children with ID in SLB. }\end{array}$ & & & & \\
\hline 10 & $\begin{array}{l}\text { The FMS learning model developed can } \\
\text { optimize the FMS of children with ID in SLB. }\end{array}$ & & & & \\
\hline
\end{tabular}

Testing the validity of the learning model activity in the morning was carried out by correlating the scores of the items observed with the total scores. A trial was conducted to find the value of the relationship and the direction of the relationship. Values range from 0 to 1 or 0 to -1 . The positive and negative signs indicate the direction of the relationship[10]. The trial was conducted by means of an inter-rater test, using Thorndike's Anova-General Multifacet Model data analysis namely testing two variables of the type ordinal and scale with normal / parametric distribution using SPSS[11].

The next step is the reliability test. There are two types of inter-rater reliability tests, if the number of raters is 2 people, the reliability test uses the inter-rater agreement correlation coefficient test, and if the number of raters is more than 2 people, the reliability test uses the correlation coefficient test between classes Intra class Correlation Coefficients (ICC). How does one know whether the sample sizes are large enough to discriminate organizations reliably from the grand mean? One way to assess this is to compute the reliability of the sample 
means, which can be computed from the intra class correlation and the sample sizes. We will call this reliability the intra class reliability to avoid confusion with other forms of reliability and intra class correlations. \{Formatting Citation

This study used 3 raters so that it used the correlation coefficient test between classes or ICC. The instrument reliability test was tested on 10 students for grade 1 SDLBC Karya Ibu Palembang.

The test of the effectiveness of the learning model activities in the morning uses a performance assessment instrument (rubric assessment) which consists of 4 aspects, namely; aspects of movement skills, cognitive aspects, pleasure aspects and attention focus aspects (Table 1, Table 2, and Table 3).

\subsection{Result}

This study used a rating scale instrument to assess the feasibility of the draft FMS development model through playing activities children with mild ID. Sumaryanti, et al [2013] in research entitled Improving Basic Movements and Health of Mentally Disabled Students. Through Adaptive Physical Activities used to rating scale to assess model was developed for expert validation. Before small group trials, assess the feasibility of the developed model. The assessment was carried out by experts (4 experts) and practitioners (teachers who implement). The results of the expert validation test were to determine the validity level of the learning model activities in the morning by 4 experts, and the results of the expert's assessment and the results of data analysis using CVR were as follows:

Table 6. CVR Test Results for Learning Model “Activities in the Morning”

\begin{tabular}{|c|c|c|c|c|c|c|c|c|c|c|}
\hline No. & E1 & E1 & E1 & E1 & ne & $\mathrm{N}$ & $\mathrm{N} / 2$ & $\mathrm{Ne}(\mathrm{N} / 2)$ & CVR & Criteria \\
\hline 1 & 4 & 4 & 4 & 3 & 3 & 4 & 2 & 1 & 0.5 & $\mathrm{v}$ \\
\hline 2 & 4 & 4 & 4 & 3 & 3 & 4 & 2 & 1 & 0.5 & $\mathrm{v}$ \\
\hline 3 & 4 & 4 & 4 & 4 & 4 & 4 & 2 & 2 & 1 & $\mathrm{v}$ \\
\hline 4 & 4 & 4 & 3 & 4 & 3 & 4 & 2 & 1 & 0.5 & $\mathrm{v}$ \\
\hline 5 & 4 & 3 & 4 & 4 & 3 & 4 & 2 & 1 & 0,5 & $\mathrm{v}$ \\
\hline 6 & 4 & 3 & 3 & 4 & 2 & 4 & 2 & 0 & 0 & $\mathrm{v}$ \\
\hline 7 & 4 & 4 & 3 & 4 & 3 & 4 & 2 & 1 & 0,5 & $\mathrm{v}$ \\
\hline 8 & 3 & 4 & 4 & 4 & 3 & 4 & 2 & 1 & 0,5 & $\mathrm{v}$ \\
\hline 9 & 3 & 4 & 4 & 4 & 3 & 4 & 2 & 1 & 0,5 & $\mathrm{v}$ \\
\hline 10 & 4 & 4 & 4 & 4 & 4 & 4 & 2 & 2 & 1 & $\mathrm{v}$ \\
\hline Total & 38 & 38 & 37 & 38 & \multicolumn{4}{|c|}{ Total } & 5.5 & \\
\hline Average & 3.8 & 3.8 & 3.7 & 3.8 & \multicolumn{4}{|c|}{ Average } & 0.55 & $\mathbf{v}$ \\
\hline Average & \multicolumn{4}{|c|}{3.78} & & & & & & \\
\hline
\end{tabular}

CVR scores on each item ranged 1 to -1

\section{Information;}

ne: Total Essential Subject Matter Expert (SME)

$\mathrm{N}$ : Total of Subject Matter Expert

$\mathrm{v}$ : Valid 
The results of the CVR analysis of the activity model in the morning (table 6) show a value of 0.55 , which means that the contents of the FMS learning model activities in the morning are appropriate or relevant or good, and also have high content validity, so that it can be continued to be tested for empirical validation.

The results of the analysis of the validity test of the activities in the morning learning model instrument can be seen in table 7 below:

Table 7. Instrument Validity Test Results for Learning Model “Activities in The Morning”

\begin{tabular}{|c|c|c|c|c|}
\hline Aspect & Score Rater & $\begin{array}{l}\text { Coefficient } \\
\text { Correlation }\end{array}$ & $\mathrm{P}$ & Status \\
\hline \multirow{3}{*}{$\begin{array}{l}\text { Movement } \\
\text { Skill }\end{array}$} & $\begin{array}{c}\text { Rater } 1 \text { - score } \\
\text { total rater }\end{array}$ & 0,918 & 0,05 & Valid \\
\hline & $\begin{array}{c}\text { Rater } 2 \text { - score } \\
\text { total rater }\end{array}$ & 0,910 & 0,05 & Valid \\
\hline & $\begin{array}{c}\text { Rater } 3 \text { - score } \\
\text { total rater }\end{array}$ & 0,690 & 0,05 & Valid \\
\hline \multirow{3}{*}{$\begin{array}{l}\text { Cognitive } \\
\text { Skill }\end{array}$} & $\begin{array}{c}\text { Rater } 1 \text { - score } \\
\text { total rater }\end{array}$ & 0,729 & 0,05 & Valid \\
\hline & $\begin{array}{c}\text { Rater } 2 \text { - score } \\
\text { total rater }\end{array}$ & 0,753 & 0,05 & Valid \\
\hline & $\begin{array}{c}\text { Rater } 3 \text { - score } \\
\text { total rater }\end{array}$ & 0,656 & 0,05 & Valid \\
\hline \multirow{3}{*}{ Fun } & $\begin{array}{c}\text { Rater } 1 \text { - score } \\
\text { total rater }\end{array}$ & 0,747 & 0,05 & Valid \\
\hline & $\begin{array}{c}\text { Rater } 2 \text { - score } \\
\text { total rater }\end{array}$ & 0,644 & 0,05 & Valid \\
\hline & $\begin{array}{c}\text { Rater } 3 \text { - score } \\
\text { total rater }\end{array}$ & 0,696 & 0,05 & Valid \\
\hline \multirow{3}{*}{$\begin{array}{l}\text { Focus } \\
\text { Attention }\end{array}$} & $\begin{array}{c}\text { Rater } 1 \text { - score } \\
\text { total rater }\end{array}$ & 0,849 & 0,05 & Valid \\
\hline & $\begin{array}{c}\text { Rater } 2 \text { - score } \\
\text { total rater }\end{array}$ & 0,721 & 0,05 & Valid \\
\hline & $\begin{array}{c}\text { Rater } 3 \text { - score } \\
\text { total rater }\end{array}$ & 0,703 & 0,05 & Valid \\
\hline
\end{tabular}

Based on the results of the calculation of the correlation coefficient between rater test data of the instrument learning model activities in the morning on aspects of movement skills, cognitive aspects, fun aspects and attention focus aspects, it is known that there is a relationship between rater 1 scores and total rater scores which have a high degree of positive relationship, and the relationship between rater score 2 and rater total score has a high degree of positive relationship, and also the relationship between rater score 3 and total score between raters has a high degree of positive relationship

The next activity carried out by the researcher was to test the reliability of the learning model activities in the morning using the Intra class Correlation Coefficient (ICC) test with 3 rater, while the result data can be seen in table 8 below:

Table 8. Instrument Reliable Test Results for Learning Model "Activities in The Morning"

\begin{tabular}{|c|c|c|c|}
\hline Aspect & Coefficient & $\begin{array}{c}\text { Coefficient } \\
\text { Inter Rater }\end{array}$ & Status \\
\hline $\begin{array}{c}\text { Movement } \\
\text { skill }\end{array}$ & 0,905 & 0,826 & Reliable \\
\hline $\begin{array}{c}\text { Cognitive } \\
\text { skill }\end{array}$ & 0,894 & 0,809 & Reliable \\
\hline fun & 0,770 & 0,627 & Reliable \\
\hline $\begin{array}{c}\text { Focus } \\
\text { attention }\end{array}$ & 0,838 & 0,772 & Reliable \\
\hline
\end{tabular}

Based on the results of the ICC test 3 rater, it can be concluded that the reliability value of the four aspects is estimated using the Alpha coefficient, with data analysis using the Anova General Multifacet Model, showing the coefficient value and coefficient value between rater is high. After the results of the data analysis of the activities in the morning instrument learning model were declared valid and reliable, the researchers proceeded to the empiric test (field trials) on the products developed, namely by conducting small group trials and large group trials to determine the effectiveness of the product being developed. The results of the field trials are as follows;

(1) Test the effectiveness of small group trial products

The results of the analysis of the different learning model activities in the morning in small group trials for aspects of movement skills, cognitive skill, fun, and focus of attention in small group trials obtained an average value of trial 2 greater than trial 1. So Also, the calculated z-test is greater than the z-table value, so the difference is significant. It can be seen in the table 9 below;

Table 9. The Effectiveness Test of Learning Model “Activities in The Morning” in Small Group Trial

\begin{tabular}{|c|c|c|c|c|c|c|c|c|}
\hline \multirow{3}{*}{ Trial } & \multicolumn{8}{|c|}{ ASPECT } \\
\hline & \multicolumn{2}{|c|}{ Movement Skill } & \multicolumn{2}{|c|}{ Cognitive Skill } & \multicolumn{2}{|c|}{ Fun } & \multicolumn{2}{|c|}{ Focus Attention } \\
\hline & M & $\mathrm{Z}$ test & M & $\mathrm{Z}$ test & M & $\mathrm{Z}$ test & M & $\mathrm{Z}$ test \\
\hline Trial 1 & 7.3 & \multirow{2}{*}{2.92} & 7.9 & \multirow{2}{*}{2.91} & 7.9 & \multirow{2}{*}{2.84} & 7.9 & \multirow{2}{*}{2.72} \\
\hline Trial 2 & 10 & & 9.3 & & 9.7 & & 9.3 & \\
\hline Z score & & 1.96 & & 1.96 & & 1.96 & & 1.96 \\
\hline
\end{tabular}


Table 10. The Effectiveness Test of Learning Model “Activities in The Morning” in Large Group Trial

\begin{tabular}{|c|c|c|c|c|c|c|c|c|}
\hline \multirow{3}{*}{ Trial } & \multicolumn{8}{|c|}{ ASPECT } \\
\hline & \multicolumn{2}{|c|}{ Movement Skill } & \multicolumn{2}{|c|}{ Cognitive Skill } & \multicolumn{2}{|c|}{ Fun } & \multicolumn{2}{|c|}{ Focus Attention } \\
\hline & M & $\mathrm{Z}$ test & M & $\mathrm{Z}$ test & M & $\mathrm{Z}$ test & M & $\mathrm{Z}$ test \\
\hline Trial 1 & 7.4 & \multirow{2}{*}{4.25} & 8.1 & \multirow{2}{*}{3.66} & 8.3 & \multirow{2}{*}{2.77} & 7.5 & \multirow{2}{*}{3.78} \\
\hline Trial 2 & 9.6 & & 9.1 & & 9.1 & & 9.2 & \\
\hline Z score & & 1.96 & & 1.96 & & 1.96 & & 1.96 \\
\hline
\end{tabular}

\section{(2) Test the effectiveness of large group trial products}

The results of the analysis of the different learning model activities in the morning in small group trials for aspects of movement skills, cognitive skill, fun, and focus of attention in large group trials obtained an average value of trial 2 greater than trial 1. So Also, the calculated z-test is greater than the z-table value, so the difference is significant. It can be seen in the table 10 .

From the data that have been presented, it can be concluded that learning model activities in the morning is effective for improving fundamental movement skill, cognitive skill, fun, and focus of attention of children with mild ID 8-10 years old male and female in SDLB C.

\subsection{Discussion}

The researcher gives suggestions when implementing the game; (1) it is better if after the teacher provides instructions regarding the procedure for implementing the game, the teacher immediately gives the opportunity to students to try it, (2) the teacher gives the first opportunity to students who are enthusiastic about playing the game, (3) the teacher uses easy language that children understand in delivering this game activity material, (4) the teacher gives special attention by giving praise to children's activities, (5) the teacher should first save the equipment or game media that will not be used in an effort to focus children's attention, (6) there was no significant difference between the skills possessed by boys and girls students, so the process of implementing learning material for fundamental movement skills should not differentiate between male and female students.

How information is presented to students with intellectual disabilities often makes the difference between success and failure. In general, learning enhanced if it is fun, ensures success, and keeps the student active. Because students with intellectual disabilities need more time and opportunities to learn new skills, and good teachers plan an active class and provide many opportunities for students to practice targeted skills. They also carefully select teaching methods to match the students' level of cognitive development[12].

Learning children with mild ID must be carried out with simple instructions and accompanied by direct and concrete demonstrations to make it easier for children with ID to accept because children with ID are slower in cognitive development, and their mental operations might be confined to concrete objects and events. Verbal instructions with examples of the correct movements will be easier to imitate by children with ID, therefore the teacher places more emphasis on practicing the movements that the child must do.

Research was conducted by Sumaryanti, et al[13]. The results showed that the Adaptive Physical Activity model could optimize the brain of mentally children with ID. Hayakawa and Kobayashi[14], The researched results show that the physical ability training program and movement are designed to improve speed and balance, physical performance, and the results of the questionnaire show that the program has benefits for the sample studied and increases excitement for them in participating in each training session. Dandashi, et al[15] was resulted show is to promote learning, memorization, and physical movements while having fun. The game can be easily adapted to the specific needs of each level of the mental retardation category. The results collected showed a positive impact on children's cognitive abilities in terms of grades, understanding of guidelines, coordination, concentration, communication and memorization skills.

FMS learning model for activities in the morning is designed based on the needs of children with mild ID. After being validated, analyzed and got relevant results by experts, this model will be tested in the small and large scale trial stages on teachers and students in primary school special education in Palembang City.

\subsection{Conclusion}

(1) The results of the CVR analysis of the activity model in the morning show a value of 0.55 (is between 1 and -1) which means that the contents of the FMS learning model activities in the morning are appropriate or relevant or good, and also have high content validity.

(2) The results of the calculation of the correlation coefficient between rater test data of the instrument learning model activities in the morning on aspects of movement skills, cognitive aspects, fun aspects and attention focus aspects, it is known that there is a relationship between rater 1 scores and total rater scores which have a high degree of positive relationship, and the relationship between rater score 2 and rater total score has a high degree of positive 
relationship, and also the relationship between rater score 3 and total score between raters has a high degree of positive relationship $(>0,05)$.

(3) The results of the effectiveness test analysis of the different learning model activities in the morning in small and large group trials for aspects of movement skills, cognitive skill, fun, and focus of attention in trials small and large group obtained an average value of trial 2 greater than trial 1 . (z-test $>$ z-table) so the difference is significant.

This research produces a product in the form of a learning model activities that can improve fundamental movement skills, cognitive skill, fun and focus of attention for children within mild ID aged 8-10 years old boys or girls, using safe, inexpensive, educational and fun media for children. This game learning model is recommended not only for teachers in special schools but for parents who have children with special needs, especially children with mild ID and children who have problems / obstacles in learning movement.

\section{REFERENCES}

[1] K. H. Alshamri, "Challenges and experiences of high school teachers with students having intellectual disabilities in inclusive classrooms in Saudi Arabia," Univers. J. Educ. Res., vol. 8, no. 5, pp. 2191-2196, 2020, doi: 10.13189/ujer.2020.080559.

[2] B. Akyol and M. Ilkim, "Effect of table tennis training on reaction times of down-syndrome children," Univers. J. Educ. Res., vol. 6, no. 11, pp. 2399-2403, 2018, doi: 10.13189/ujer.2018.061101.

[3] P. Zikl, N. Holoubková, H. Karásková, and T. B. Veselíková, "Gross Motor Skills of Children with Mild Intellectual Disabilities,” Int. J. Soc. Behav. Educ. Econ. Bus. Ind. Eng., vol. 7, no. 10, pp. 2789-2795, 2013.

[4] S. Carrascal and Y. G. Rodríguez, "The Influence of Teacher Training for the Attention of Students with Intellectual Disabilities in the Transitional Period to Adulthood,"
Univers. J. Educ. Res., vol. 5, no. 11, pp. 1863-1868, 2017, doi: 10.13189/ujer.2017.051102.

[5] S. A. Kesumawati, T. Rahayu, H. A. R, and S. Rahayu, "Game Model To Increase Fundamental Movement Skills in Children With Mild Intellectual Disability,” vol. 247, no. Iset, pp. 431-436, 2018.

[6] M. McKeon, E. Slevin, and L. Taggart, "A pilot survey of physical activity in men with an intellectual disability," $J$. Intellect. Disabil., vol. 17, no. 2, pp. 157-167, 2013, doi: $10.1177 / 1744629513484666$.

[7] T. Sullivan, C. Slagle, T. J. Hapshie, D. Brevard, and V. Brevard, Build It So They Can Play Affordable Equipment Education. 2012.

[8] Atesya, Selvi, Rahayu, T. Activity model of playing: my hero is my mother to improve basic oovement skills of mild mental retarded children. Journal Physical Education, Helath and Recreation Vol. 4 No1 (2019), 52-61. 2019

[9] J. L. Ellis, "Probability interpretations of intraclass reliabilities,” Stat. Med., vol. 32, no. 26, pp. 4596-4608, 2013, doi: 10.1002/sim.5853.

[10] Trihendardi, Cornelius. "Step Easily Solve Statistical Cases : Descriptive, Parametric And Non Parametric With SPSS 12” Yogyakarta: Andi Offset, 2013.

[11] E. Susanto, "Pengembangan tes keterampilan dasar olahraga bola tangan bagi mahasiswa,” J. Penelit. dan Eval. Pendidik., vol. 21, no. 1, pp. 116-125, 2017, doi: 10.21831/pep.v21i1. 15784 .

[12] Winnick, J. P. (2005). Adapted physical education sport. Champaign, IL, Human Kinetics.

[13] Sumaryanti, T Rahayu, H Amirullah, S Rahayu. Improving basic movements and health of mentally disabled students through adaptive physical activities. The Journal of Educational Development, 2013.

[14] Hayakawa, K., \& Kobayashi, K. Physical and Motor Skill Training for Children with Intellectual Disabilities. Perceptual and Motor Skills, 112(2), 573-580. 2011.

[15] Dandashi, A., Karkar, A. G., Saad, S., Barhoumi, Z., Al-Jaam, J., \& El Saddik, A. Enhancing the cognitive and learning skills of children with intellectual disability through physical activity and edutainment games. International Journal of Distributed Sensor Networks, 2015. 